ELORE (ISSN 1456-3010), vol. $16-1 / 2009$.

Julkaisija: Suomen Kansantietouden Tutkijain Seura ry. [http://www.elore.fi/arkisto/1_09/hamalainen_01_09.pdf]

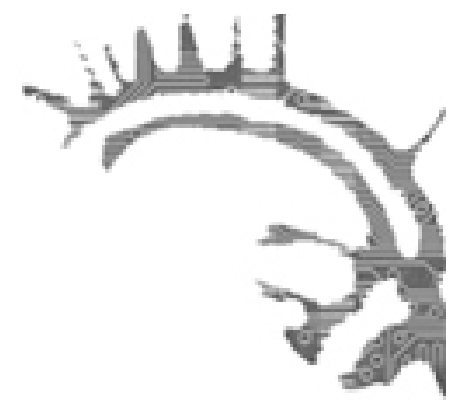

Ajankohtaista:

\title{
TulKINTOJA JA VUOROPUHELUJA IDENTITEETEISTÄ
}

Identiteetit 1800-luvulla. Identiteter på 1800-talet. 1800-luvun tutkimuksen verkoston ensimmäinen vuosikonferenssi. Nätverket för 1800-talsforsknings första årskonferens 22.-23.1.2009, Suomalaisen Kirjallisunden Seura, Helsinki

\section{Niina Hämäläinen}

Kaksipäiväinen seminaari Identiteetit 1800-luvulla oli virkistävä avaus uudelta 1800-luvun tutkimuksen verkostolta, joka perustettiin syksyllä 2008. Monitieteellinen tapaaminen Suomalaisen Kirjallisuuden Seuran (SKS) tiloissa keräsi kolmisenkymmentä esitelmää ja lähes sata kuulijaa ympäri Suomea. Seminaari oli jaettu erillisiin, päällekkäisiin temaattisiin istuntoihin.

\section{SUOMALAISUUTTA HAHMOTTAMASSA}

Itseäni kiinnostivat esitelmät, jotka lähestyivät identiteettejä 1800-luvun sosiaalisen kontekstin kautta. "Sivistyneistö ja suomalaisuus" -istunnossa oli kolme puheenvuoroa, joista kaksi ensimmäistä tarkasteli "suurmiesten" käsityksiä siitä, mitä suomalaisuus tarkoitti 1800-luvulla. Klaus Lindgren yhteiskuntahistorian laitokselta Helsingin yliopistosta (HY) eritteli Johan Vilhelm Snellmanin, Zacharias Topeliuksen ja Johan Ludvig Runebergin suomalaisuuskäsityksiä kielipoliittisten kannanottojen kautta. Noista kolmesta Snellman, alunperin ruotsinkielinen, oli ehdottomin kannassaan: kansakunnan ja kansalaisten kieli on suomi. Runebergin ja Topeliuksen ajatukset olivat ymmärtäväisempiä, heille kaikki Suomessa asuvat ovat suomalaisia, kieleen katsomatta. Kulttuurihistorioitsija Heli Rantalan (Turun yliopisto) esitelmä valotti Snellmanin toimintaa laajemmin. Rantala halusi korostaa, että Snellmanin ajatuksia suomalaisuudesta on liikaakin vedetty kielipoliittisiin kysymyksiin. Snellmanille suomalaisuus merkitsi myös muuta, se oli kansallinen yhteisymmärrys, ajattelu ja kulttuuri eli kansallinen identiteetti. 


\section{TULKINTOJA JA VUOROPUHELUJA IDENTITEETEISTÄ}

Istunnon kolmas esitelmä esitteli suomalaisuuden kytköksiä uuteen teknologiaan ja maisemaan. Historioitsija Tïna Päivärinne (HY) kartoitti mielikuvia teknologiasta ja sitä, miten se esiteltiin myönteisessä valossa kansalle. Hänen väitöskirja-aineistonaan on 1800-luvun lopun kansanvalistuksellinen kirjallisuus. Esimerkiksi puuteollisuuden katsottiin edustavan kansallisen teknologian ja sitä kautta sivistyneistön kuvastoa.

\section{SIVISTYNEISTÖN JA KANSAN EROT JA KOHTAAMINEN}

Seuraava istunto keskittyi lääkärin ja kansan väliseen vuorovaikutukseen. Lääketieteen tohtori Jorma Rantanen oli estynyt tulemasta paikalle, joten SKS:n erikoistutkija Raija Majamaa luki Rantasen pyynnöstä tämän paperin. Rantanen oli otsikoinut esitelmänsä "Piirilääkäri Elias Lönnrot ja potilaan kohtaaminen". Rantanen, itsekin lääkäri, lähestyi Lönnrotin lääkäriyttä vuorovaikutuksen näkökulmasta. Lönnrotin vuorovaikutus potilaan kanssa toimi Rantasen mukaan yksilön, yhteisön ja yhteiskunnan tasoilla. Rantasen esitelmä osoitti selvästi, kuinka moderni lääkäri Lönnrot aikanaan oli: kliinisten apuvälineiden puuttuessa lääkärintyö perustui kokonaisvaltaisesti potilaan kuuntelemiselle ja havainnoimiselle.

Majamaan oma puheenvuoro keskittyi Lönnrotin lääkärin työhön kirjeenvaihdon valossa otsikolla "Kansan kipu ja kollegoiden verkosto Elias Lönnrotin kirjeenvaihdossa". Mahdollisuudet edetä lääkäriksi, päästä osaksi sivistyneistöä sekä sivistyä eivät olleet itsestäänselviä asioita torpparitaustaiselle Lönnrotille. Erityisesti arkkiatri J. A. Törngrenin perheen henkinen ja taloudellinen suosio edistivät nuoren kotiopettajan urakehitystä. Tästä huolimatta Lönnrot eli sivistyneistön ja tavallisen kansan välissä. Majamaa korosti puheessaan Lönnrotin tarkkailijan roolia sekä lääkärinä että ulkopuolisena sivistyneistön edustajana Kajaanin seurapiireissä.

Iltapäivän istunto "Kansalle rakennettu kulttuuri” keskusteli aamupäivän esitelmien kanssa siinä mielessä, että se veti yleisempiä linjoja 1800-luvun sivistyneistön valistus- ja kulttuurityöhön. Historiantutkija Heikki Kokko Tampereen yliopistosta (TaY) hahmotteli sivistyneistön ja kansan identiteettien erilaisuutta kulttuurikäsityksen kautta. Sinänsä kiinnostavassa esitelmässä itse kulttuurikäsitys jäi hieman epäselväksi. Kokon mukaan sivistyneistön käsitys omasta identiteetistään rakentui suhteessa käsitykseen kulttuurista ja muista kulttuureista. Käsitykset muodostuivat ylikansallisessa tilassa, jossa keskeistä oli suunta ulospäin, suhde ulkomaailmaan, eurooppalaisuuteen ja länsimaalaisuuteen. Kysymys siitä, miten kansan ymmärrys omasta identiteetistään ja paikastaan Suomessa rakentui, jäi esityksessä käsittelemättä. Siihen tosin saatiin vastauksia seuraavan päivän istunnossa "Sivistyneistön ja kansan vuoropuhelu".

Folkloristi Jouni Hyvönen (HY) tarttui puheenvuorossaan Elias Lönnrotin Kalevalan tieteellisiin päämääriin. Lönnrotia ajoi eteenpäin täydellisyyden idea. Täydellisyyden tavoittaminen oli mahdollista kuvaamalla mahdollisimman monipuolisesti entisajan maailmaa, sisällyttämällä kattava kansanrunoaineiston ja -lajien esittely, pyrkimällä niin kielen, tyylin kuin kuvauksen suhteen autenttisuuteen. Hyvönen halusi ottaa esitelmässään esiin myös sen, että Lönnrot työsti Kalevalaa hyvinkin kollektiivisesti muiden kansanrunoharrastajien kanssa kopioiden muiden keräämiä runoja ja kysyen 


\section{NiINA HäMÄLÄINEN}

neuvoa Kalevalan kokoonpanosta, seikka, jota aikaisempi tutkimus ei ole tarpeeksi huomioinut. Kiinnostavaa onkin pohtia Hyvösen ajatusten seurauksena sitä, mikä oli Kalevalan todellinen yleisö: kenelle Lönnrot eeposta kirjoitti ja miten "kansallinen" eeposprojekti todellisuudessa oli?

\section{MolemminpuOlista?}

Miten kansankirjoittajat määrittelivät itseään ja toisaalta sivistyneistön edustajia kirjoituksissaan on kysymys, jota useiden esitelmien sisällöt koskettivat perjantaiaamupäivän kaksiosaisessa istunnossa "Sivistyneistön ja kansan vuoropuhelu".

Historiantutkija Kaisa Kauranen (HY) esitteli yhden kansankirjoittajan, Gustaf Fredrik Braskin (1829-1906) käsityksiä itsestään ja kirjallisesta toiminnastaan. Kuten monet kansankirjoittajia käsittelevät tutkimukset ovat osoittaneet (Laurila 1956, Makkonen 2002, Kurki 2002, Lassila 2008), halu oppia ja ilmaista ajatuksiaan kirjoittamalla teki kansankirjoittajista eräänlaisia poikkeusyksilöitä. Kirjoittavana kansanihmisenä Brask oli sivistyneistön ja kansan välittäjä. Kauranen korosti Braskin moraalista kynää, joka osoitti niin sivistyneistön asenteisiin kuin tavallisen torpparin eli leipätyöntekijöiden (Braskin oma termi) haluttomuuteen kohottaa omaa elintasoaan. Braskilla oli tarve muuttaa maailmaa kirjoitustensa kautta ja niin hän usein puuttuikin yhteiskunnallisiin epäkohtiin, erityisesti torpparien oikeuksiin. Brask ei koskaan saanut julkaistua kirjoituksiaan ja vasta nykytutkijat ovat löytäneet Braskin kirjoitukset arkistojen kätköstä.

Kirjallisuudentutkija ja SKS:n Kirjallisuusarkiston johtaja Anna Kuismin (ent. Makkonen) jatkoi Kaurasen tematiikkaa tarkastelemalla sitä, miten kansankirjoittajat määrittelivät herroja omissa teksteissään. Kuismin jakoi esimerkkitekstejä ja haastoi yleisön ottamaan kantaa tekstien kieleen ja tyyliin. Kuisminin oma ensireaktio tekstejä lukiessa oli hämmennys ja kiusaannus: miksi kirjoittaja puhuu kansasta lapsina, joita herrat ohjaavat? Omien ristiriitaisten tunteidensa julkituomisella Kuismin halusi osoittaa, miten meidän nykylukijoiden on yritettävä asettua 1800-luvun kansankirjoittajan asemaan eikä tulkita tämän ajatuksia vain omasta tutkijanperspektiivistämme. Kuismin kysyikin, mitkä olivat kontekstuaaliset lähtökohdat ja edellytykset sille, että tavallinen kansanihminen pystyi tuottamaan omia ajatuksiaan kirjallisen tekstin muodossa.

Jos Kaurasen ja Kuisminin esitelmistä välittyi kansanihmisen jonkinlainen nöyrä ja ihailevakin suhtautuminen sivistyneistöön, hahmotteli kansan ja sivistyneistön suoranaista eripuraa historiantutkija Sami Suodenjoki (TaY) esitelmässään maanjakohuhuista. Huhut alkoivat levitä jo 1830-luvulla, vaikka helmikuun manifestia vuonna 1899 onkin pidetty huhuaallon huippuna. Suodenjoki havainnollisti, kuinka huhut tekivät näkyväksi tilattoman väestön kokeman epäoikeudenmukaisuuden maanjaon suhteen. Voikin ajatella, että huhuissa oli paljolti kyse kansan oikeudenmukaisuuden tajusta ja yrityksestä vastustaa ylhäältä päin tulevia käskyjä. Maanjakohuhuihin liittyivät myös sivistyneistön suoranaiset vastatoimet huhujen lopettamiseksi tai vähintään niiden mitätöimiseksi. 


\section{TULKINTOJA JA VUOROPUHELUJA IDENTITEETEISTÄ}

Kirjoittamisen kautta kansanihminen tuli myös enenevässä määrin tietoiseksi itsestään, yhteiskunnasta ja sen epäkohdista. Folkloristi Kirsti Salmi-Niklander (HY) oli estynyt tulemasta paikalle, mutta hänen oli märä puhua uudenlaisesta kirjallisesta vaikuttamisesta, joka tuli mahdolliseksi 1800-luvun lopulla. Osakunnat, raittiusseurat ja työväenyhdistykset toimittivat käsinkirjoitettuja lehtisiä, jotka usein kuvailivat paikallisyhteisön kollektiivisia tapahtumia kuten markkinoita tai kokouksia erilaisten sosiaalisten ryhmien jännitteiden kautta. Salmi-Niklanderin tutkimuksellinen ongelma koskettaa kaikkia menneen aineiston parissa työskenteleviä: miten tavoittaa jännitteet, vivahteet ja ihmisten välinen vuorovaikutus kirjallisista lähteistä ja aukkoisista historiallisista aineistoista?

Uudenlaista luokkatietoisuutta, joka mahdollistui työväenluokan synnyn jatkeena, käsitteli kirjallisuudentutkija Kati Launis (TY). Hänen aiheenaan oli työväenkirjailija Kössi Kaatra (1882-1928) ja tämän proosakertomus Äiti ja poika (1924). Launiksen mukaan Kaatran kasvukertomuksesta voi lukea sekä kurjuutta omasta työväentaustasta että toivoa paremmasta tulevaisuudesta. Siinä on myös piirteitä ilosta ja riemusta, jonka aiheuttaa yhteinen, joukolla koettu herääminen luokkatietoisuuteen. Kaatran teoksessa luokkatietoisuus ei kuitenkaan ole staattinen ilmiö, vaan sen rajoja on mahdollista liikuttaa ja jopa karnevalistisesti kumota ainakin hetkellisesti, esimerkiksi sivistyneistön ja työväen yhteisen humalatilan aikana.

Varhaisten kansankirjoittajien tietoisuus sosiaalisista eroista on näkyvissä heidän teksteissään, kuten Braskilla esimerkiksi "leipätyöntekijöiden” aseman kurjuus. Erona 1800-luvun ja 1900-luvun vaihteen kirjailijoihin on kuitenkin se, että muutoksen hakeminen oli vielä sovinnaista ja valistuksellista. Myös suhde toisaalta omiin, toisaalta sivistyneistöön oli vähintään kaksipuolinen: molempia haluttiin valistaa ja moittia. 1900-luvun alun kirjoittaja Kössi Kaatra ei enää valistanut, ei pyrkinyt ylös eikä alas. Hänelle luokkatietoisuus tuntui olevan, Launiksen esitelmän perusteella, mahdollisuus sosiaalisesti tasa-arvoiseen yhteiskuntaan.

Kirjallisuudentutkija Heidi Grönstrand (TY) lähestyi puheenvuorossaan Kössi Kaatran aikalaisen kirjailija Kersti Bergrothin (1886-1975) kirjailijaidentiteettiä. Bergroth, joka tunnetaan parhaiten Eeva-kirjoistaan, kirjoitti varhaistuotantonsa ruotsiksi, mutta vaihtoi myöhemmin kielen suomeksi. Tällöin myös laji muuttui. Tätä lajin ja kielen yhteyttä Grönstrand aikoo tarkemmin tutkia vasta aluillaan olevassa tutkimuksessaan: oliko kyse valistamisesta, persoonallisuudesta - vai yksinkertaisesti toimeentulon turvaamisesta, kuten Anna Kuismin ehdotti? Kansankirjoittajan asemaa luonnehtii välittäjän rooli kansan ja sivistyneistön välillä. Myös sivistyneistön edustaja saattoi toimia välittäjänä molempiin suuntiin, etenkin jos hänellä oli kokemusta molemmista maailmoista. Omassa esityksessäni puhuin siitä, miten Lönnrot työsti Kalevalaa vuosien varrella yhä enemmän suhteessa oman aikansa perhekeskusteluun ja kansanvalistukseen. Aino- ja Kullervo-runot osoittavat, että Lönnrot pyrki vastaamaan runonlaulajien malliin erityisesti eepoksen varhaisten versioiden kohdalla. Myöhemmin Lönnrotia ohjasi sivistyneistön käymä valistuksellinen keskustelu sekä hänen omat näkemyksensä runojen sisällöstä ja sanomasta. Mitä pidemmälle Kalevala-työskentely kehittyi, sitä hanakammin Lönnrot verhoutui kollektiivisen tekijyyden taakse. Kollektiivisuuden varjolla hän "oikeutti” äidin konnotatiiviset merkityspainotukset Kalevalassa. 


\section{NiINA HäMäLÄINEN}

\section{VUOROPUHELUA IDENTITEETEISTÄ}

Perjantaiaamun istunnon otsikosta "Sivistyneistön ja kansan vuoropuhelu" olisi voinut napata sanan "vuoropuhelu" koko seminaarin nimeen, sillä se tuli jollain tavalla esiin kaikissa seuraamissani kaksipäiväisen seminaarin esitelmissä. Identiteeteissä oli kyse ennen kaikkea vuorovaikutuksesta tavallisen kansanihmisen ja sivistyneistöön kuuluvan välillä, suhteesta, joka muokkasi molempien käsityksiä itsestä ja muista.

Identiteetit 1800-luvulla -seminaarin esitelmät kävivät keskustelua toisten kanssa, lomittuivat toisiinsa ja myös toistivat toistensa ajatuksia. Kaksipäiväisen seminaarin anti oli runsas ja keskustelua herättävä. Kiinnostavinta oli seminaarin avoin poikkitieteellisyys ja teemojen jatkuva dialogi. Osallistujien, niin esitelmöitsijöiden kuin kuulijoiden ja keskusteluun osallistuvien, suuri joukko osoitti, että 1800-lukuseminaarille oli tarvetta juuri nyt.

\section{KirJallisuUs}

KURKI, TUULIKKI 2002: Heikkei Merilänen ja keskusteluja kansanperinteestä. Helsinki: SKS.

LASSILA, PERTTI 2008: Syvistä riveistä. Kansankirjailija, sivistyneistö ja kirjallisuus 1800-luvulla. Helsinki: Gaudeamus.

LAURILA, VIHTORI 1956: Suomen rahvaan runoniekat sääty-ybteiskunnan aikana. 1 osa. Yleiset näkökohdat. Helsinki: SKS.

MAKKONEN, ANNA (toim.) 2002: Karheita kertomuksia. Itseoppineiden elämäkertoja 1800-luvun Suomesta. Helsinki: SKS.

Filosofian maisteri Niina Hämäläinen on folkloristiikan jatko-opiskelija Turun yliopistosta ja 1800-luvun tutkimuksen verkoston jäsen. 